\title{
Coprecipitation with Indium Hydroxide Followed by Flotation in a Flow System for Monitoring Copper(II) Ions in Water
}

\author{
Masataka Hiraide, Naoki Ozaki, Yong-Nam PaK ${ }^{\dagger}$, Tomokazu TaNaKa \\ and Hiroshi KawaguCHI
}

Department of Materials Science and Engineering, Nagoya University, Nagoya 464-01, Japan

\begin{abstract}
In a stream ( $\left.5 \mathrm{ml} \mathrm{min}^{-1}\right)$ of water sample, traces of copper(II) ions are quantitatively coprecipitated with indium hydroxide and floated with the aid of anionic surfactants and nitrogen bubbles. The precipitate-foam layer is continuously dissolved in $4 \mathrm{~mol} \mathrm{l}^{-1}$ nitric acid and collected at intervals. The copper is concentrated 25 -fold and determined by inductively coupled plasma-atomic emission spectrometry. The indium carrier is also determined to obtain the copper/ indium intensity ratios. The coprecipitation-flotation in a flow system responds well to the changes of copper concentrations.
\end{abstract}

Keywords Coprecipitation, flotation, copper(II) ion, indium hydroxide, water analysis

The combination of coprecipitation and flotation offers a simple and rapid separation technique. Various trace elements are quantitatively coprecipitated with collector precipitates and then floated to the solution surface with the aid of surfactants and a rising stream of gas bubbles. This convenient coprecipitation-flotation has been extensively applied to the analyses of natural water samples. ${ }^{1-3}$ To the best of our knowledge, however, there is no study on the application of this method to the continuous monitoring of heavy metals in water. This could be because collector precipitates strongly adhere to the walls of a flotation cell and precipitate particles distribute heterogeneously in a foam layer.

The present paper describes the potential of coprecipitation-flotation for continuous monitoring of heavy metals in water, by taking copper(II) ions for example. The adhesion of indium hydroxide (used as collector precipitate) is successfully overcome by collecting the foam layer with suction through a peristaltic pump. The copper/indium intensity ratios obtained by inductively coupled plasma-atomic emission spectrometry (ICP-AES) coincide well with the concentrations of copper(II) in flowing samples.

\section{Experimental}

\section{Apparatus}

The schematic diagram of a flowing system for

\footnotetext{
$\dagger$ Present address: Department of Chemistry Education, Korea National University of Education, Chungwon, Chungbuk 362-791, Republic of Korea.
}

coprecipitation-flotation is shown in Fig. 1. Coprecipitation occurs in the coiled reaction tube $(3 \mathrm{~mm}$ in diameter, $1 \mathrm{~m}$ long).

Figure 2 illustrates details of the flotation cell, which consists of two compartments connected with groundglass surfaces. The height of the sample inlet and the position of the drain were optimized in order that neither the redispersion of floated precipitates nor any loss through the drain would occur. Some gentle suction at the top of the cell was essential for the continuous collection of a foam layer containing precipitates.

A Seiko SPS $1100 \mathrm{H}$ sequential type inductively coupled plasma-atomic emission spectrometer was used under the following operating conditions: wavelengths (nm) 324.75 for copper and 230.61 for indium; RF power $1.3 \mathrm{~kW}$; argon flow rates $\left(1 \mathrm{~min}^{-1}\right) 15$ for outer, 1.0 for intermediate and 0.9 for carrier; observation height $18 \mathrm{~mm}$ above load coil.

\section{Reagents}

An indium solution $\left(1 \mathrm{mg} \mathrm{m}^{-1}\right)$ was prepared by dissolving $500 \mathrm{mg}$ of indium metal (99.9999\% purity) in $4 \mathrm{ml}$ of $7 \mathrm{~mol} \mathrm{l}^{-1}$ nitric acid and diluting to $500 \mathrm{ml}$ with water. Water, $500 \mathrm{ml}$, containing $2.5 \mathrm{~g}$ of sodium hydrogencarbonate and $2.1 \mathrm{~g}$ of sodium carbonate was used as buffer solution. A surfactant solution $(0.5 \mathrm{mg}$ $\mathrm{ml}^{-1}$ ) was prepared by dissolving $62 \mathrm{mg}$ of sodium oleate and $188 \mathrm{mg}$ of sodium dodecyl sulfate in $500 \mathrm{ml}$ of $70 \%$ ethanol.

\section{Procedure}

To the flotation cell were added $20 \mathrm{ml}$ of pure water and $1 \mathrm{ml}$ of surfactant solution and nitrogen was passed 


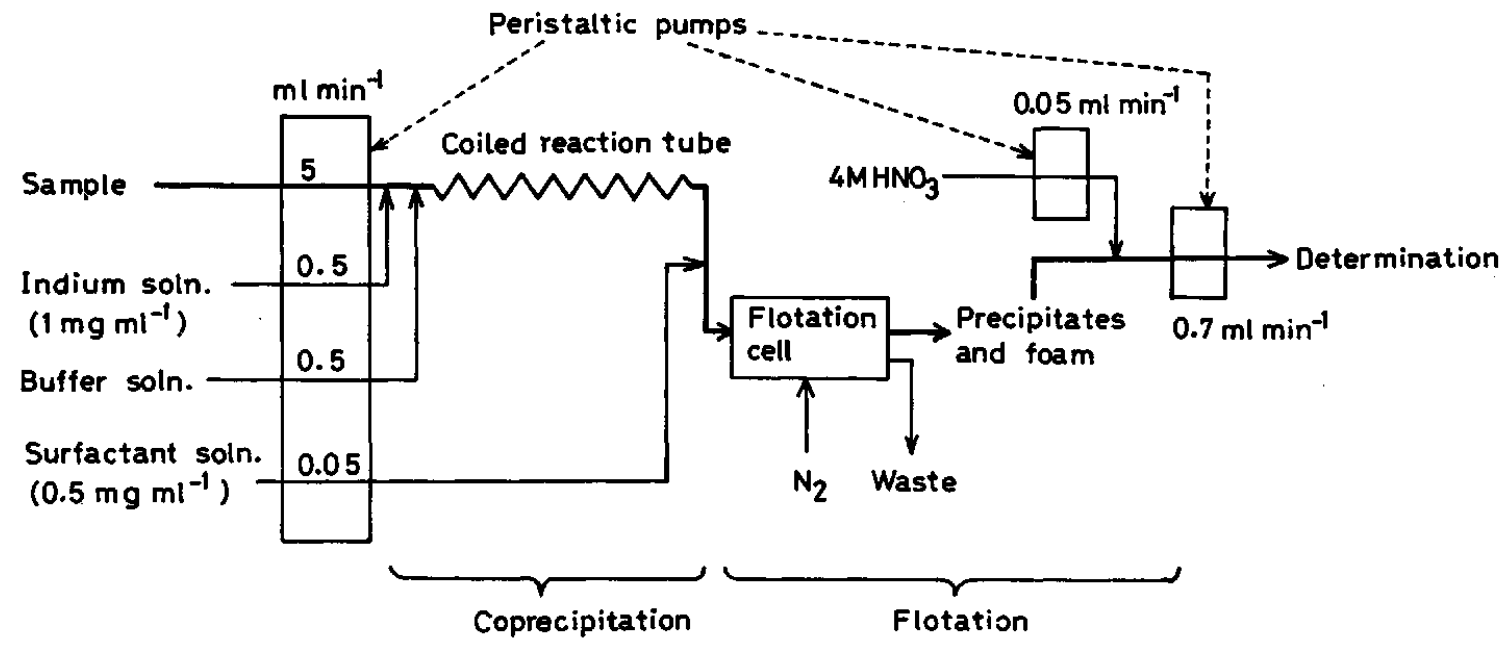

Fig. 1 Coprecipitation and flotation in a flow system.

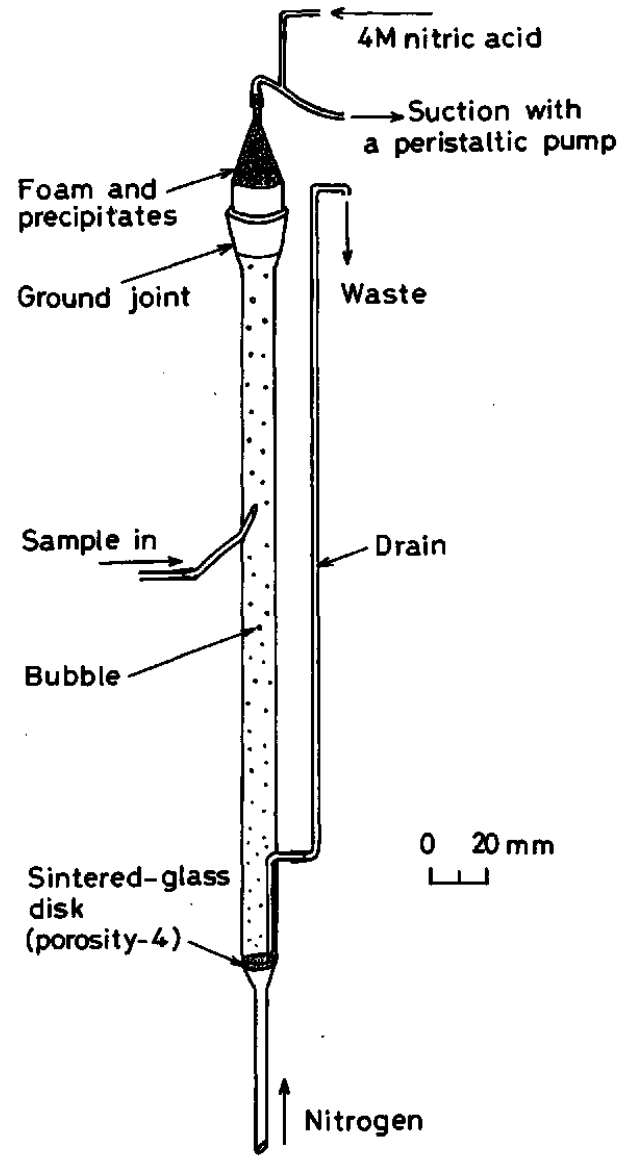

Fig. 2 Pyrex glass flotation cell for the continuous separation of precipitates.

through the sintered-glass disk at a flow rate of $2 \mathrm{ml}$ $\mathrm{min}^{-1}$ to generate numerous tiny bubbles $(0.1-0.5 \mathrm{~mm}$ in diameter). The peristaltic pumps were started to feed a water sample at a flow rate of $5 \mathrm{ml} \mathrm{min}^{-1}$ and to inject indium, buffer and surfactant solutions at $0.5,0.5$ and $0.05 \mathrm{ml} \mathrm{min}^{-1}$, respectively. In the coiled reaction tube,
copper(II) ions were quantitatively coprecipitated with indium hydroxide at pH 9-9.5. The precipitates were then floated in the flotation cell and supported on the solution surface by foam. The precipitate-foam layer was gently sucked from the top of the flotation cell by a peristaltic pump at a flow rate of $0.7 \mathrm{ml} \mathrm{min}^{-1}$. After injecting $4 \mathrm{~mol} \mathrm{l}^{-1}$ nitric acid at $0.05 \mathrm{ml} \mathrm{min}^{-1}$ to dissolve the precipitates and to rupture foam, the resulting solution was collected every $5 \mathrm{~min}$. Each fraction (ca. $1 \mathrm{ml}$ ) was analyzed by ICP-AES and the copper/indium intensity ratio was plotted as a function of collection time.

\section{Results and Discussion}

Coprecipitation of copper(II) with indium hydroxide in a flow system

The amount of indium carrier and the coprecipitation pH were determined based on the previous work..$^{4,5}$ First, the formation of indium hydroxide was examined in a flowing system. A water sample (pH 6), at $5 \mathrm{ml}$ $\mathrm{min}^{-1}$, was mixed with indium and buffer solutions at $0.5 \mathrm{ml} \mathrm{min} \mathrm{m}^{-1}$ as described in Procedure, and collected at intervals immediately after passing through the coiled reaction tube (see Fig. 1). The indium hydroxide in each fraction was dissolved with $4 \mathrm{~mol} \mathrm{l}^{-1}$ nitric acid and analyzed by ICP-AES for indium. If the indium hydroxide was formed to disperse homogeneously in the solution, the concentration of indium should be about $83 \mu \mathrm{gIn} \mathrm{ml}^{-1}$ because $0.5 \mathrm{mg}$ of indium had been injected to $6 \mathrm{ml}$ of solution (i.e., sample plus reagents) per minute. The indium concentrations, however, varied widely as shown in Fig. 3. Although an increase of collection intervals from $15 \mathrm{~s}$ to $5 \mathrm{~min}$ slightly decreased the scatter of points, it was not yet effective to obtain the constant concentrations. Therefore, the correction for indium amounts is necessary, as mentioned below.

A water sample containing copper(II) ions was mixed 


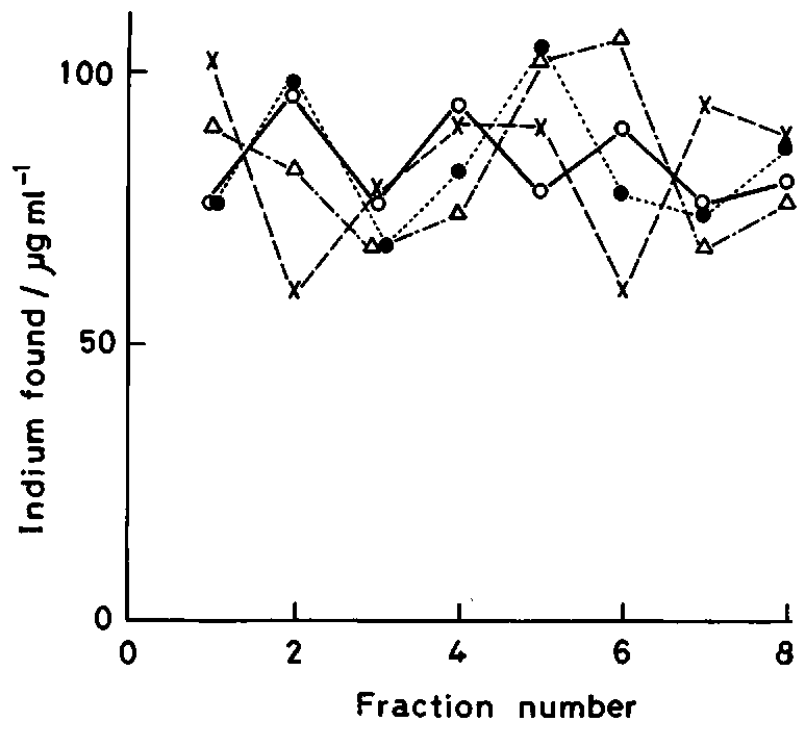

Fig. 3 Concentration of indium in eight fractions collected at intervals of $5 \mathrm{~min}(O), 3 \mathrm{~min}(\triangle), 1 \mathrm{~min}(O)$ and $15 \mathrm{~s}(\times)$.

with indium and buffer solutions in the coiled reaction tube and collected every $5 \mathrm{~min}$. In this experiment, the indium hydroxide was separated by centrifugation, instead of flotation, at $3000 \mathrm{rpm}$ for $10 \mathrm{~min}$ and dissolved in $4 \mathrm{~mol} \mathrm{l}^{-1}$ nitric acid for ICP-AES. As would be expected, the intensity of copper signal varied from fraction to fraction. The copper/indium intensity ratios, however, approached nearly constant values, which were linear to the original concentrations of copper(II) in samples (see Fig. 4). This indicates that copper(II) is homogeneously distributed on the indium hydroxide precipitates.

Flotation of indium hydroxide in a flow system

Because indium hydroxide has positively charged
Table 1 Effect of flow rate of sample on the flotation recovery of indium hydroxide

\begin{tabular}{cc}
\hline Flow rate $/ \mathrm{ml} \mathrm{min}^{-1}$ & Recovery, \% \\
\hline 2 & 98 \\
5 & 97 \\
7 & 97 \\
10 & 95 \\
15 & 93 \\
20 & 91 \\
\hline
\end{tabular}

surfaces at $\mathrm{pH} 9-9.5^{4}$, anionic surfactant ions are effectively used for rendering the precipitates hydrophobic. The combined use of sodium oleate and sodium dodecyl sulfate is most recommended for the complete flotation as well as the formation of a stable foam layer. ${ }^{4,6,7}$

The floated precipitates were gradually pushed up by foam but they adhered to the narrow part near the top of the flotation cell. This problem was overcome by using gentle suction with a peristaltic pump (see Fig. 2).

The influence of sample flow rate on the flotation of indium hydroxide was examined by analyzing the waste solution from the flotation cell. In this experiment, the amounts of indium, buffer and surfactants were adjusted in proportion to the sample volume. Table 1 shows that indium hydroxide precipitates are floated in greater than $97 \%$ yields over the range of $2-7 \mathrm{ml} \mathrm{min}^{-1}$. At higher flow rates, however, the loss of copper through the drain became significant.

\section{Continuous coprecipitation-flotation of copper(II) ions}

Direct connection of the coprecipitation-flotation with ICP-AES was first examined to find the potential of an on-line monitoring system. The resulting ICP-signals,

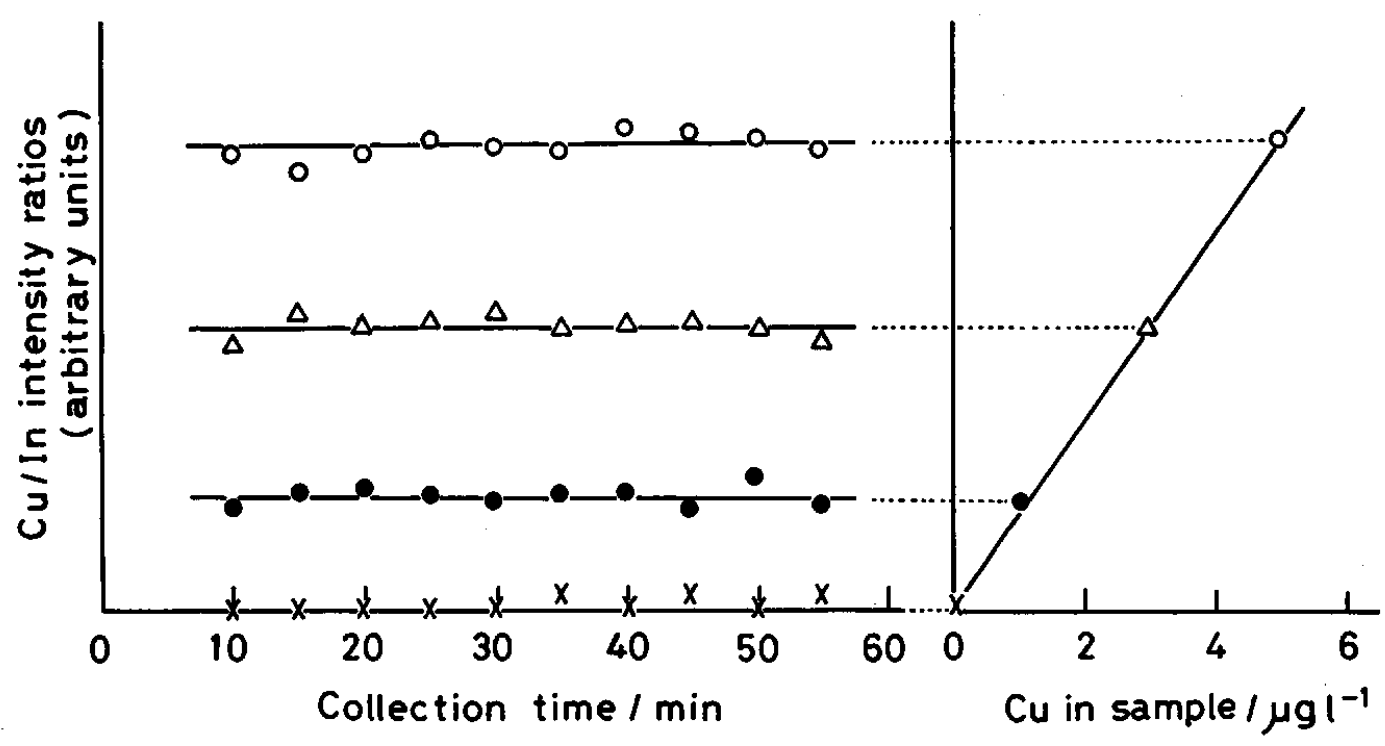

Fig. 4 Copper/indium intensity ratios for samples containing $5(O), 3(\Delta), 1(O)$ and $0(X)$ $\mu \mathrm{gCu} \mathrm{l}^{-1}$. 


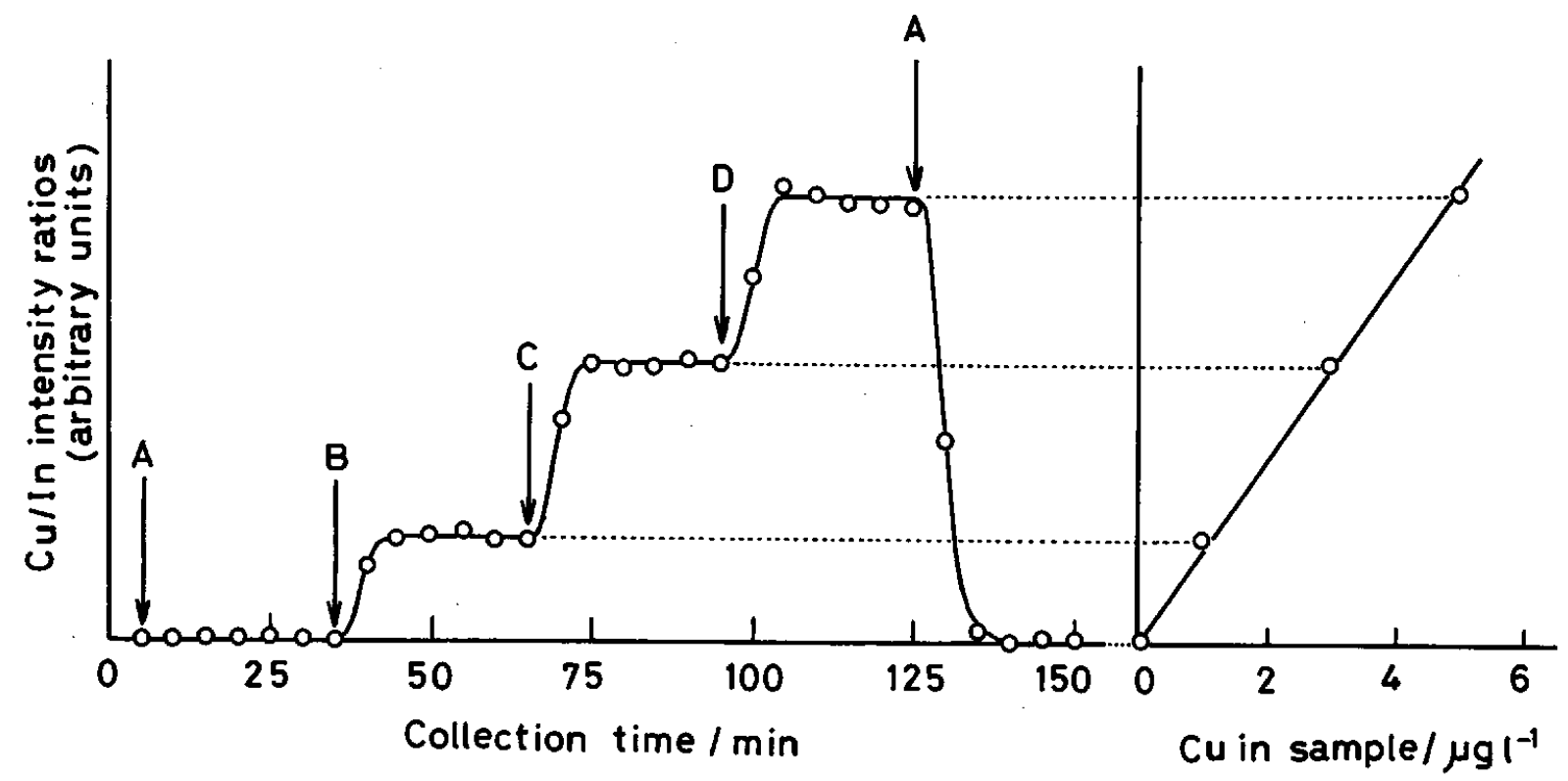

Fig. 5 Response of coprecipitation-flotation in a flow system to the change of copper concentrations. Arrows indicate the injection of samples of 0 (A), 1 (B), 3 (C) and 5 (D) $\mu \mathrm{gCu}^{-1}$.

however, were strongly affected by bubbles in the solution. Further, even if gas bubbles could be removed from the solution, the on-line monitoring system consumes much argon for the operation of ICP-AES. Therefore, it seems to be desirable to collect samples as a function of time and then determine them at the same time by ICP-AES.

Water samples (pH 6,150 ml) containing $0-750 \mathrm{ng}$ of copper(II) ions were treated as described in Procedure. The first sample $\left(0 \mu \mathrm{gCu}^{-1}\right)$ was supplied at a flow rate of $5 \mathrm{ml} \mathrm{min}-1$; coprecipitation-flotation was carried out and the final solution was collected every $5 \mathrm{~min}$ for ICPAES. Immediately after $30 \mathrm{~min}$, the second sample $\left(1 \mu \mathrm{gCu} \mathrm{l}^{-1}\right)$ started to flow; other samples were treated similarly. The volume of each fraction was about $1 \mathrm{ml}$, which resulted in a 25 -fold concentration for copper because $25 \mathrm{ml}$ of sample was treated every $5 \mathrm{~min}$. As is evident from Fig. 5, the coprecipitation-flotation in a flow system successfully responds to the change of samples and the plateau corresponds to the original concentration of copper(II) ions with a reasonable agreement (within 10\%). The memory effect can be negligible even at higher concentrations of copper(II) because the indium hydroxide has enough capacity for the complete collection of copper(II).

The concentration factor for copper(II) can be increased when a large flotation cell is used and the sample is supplied at high flow rates. Naturally occurring organic matter, e.g., humic or fulvic acid, as well as colloidal inorganic particles could not affect the proposed system. ${ }^{8,9}$ This approach can be used for monitoring different heavy metals simultaneously, in combination with ICP-AES in polychromatic system, because various heavy metals are quantitatively coprecipitated with indium hydroxide at $\mathrm{pH} 9-9.5 .4,5$

\section{References}

1. A. Mizuike, "Enrichment Techniques for Inorganic Trace Analysis", p. 94, Springer, Berlin, 1983.

2. M. Hiraide and A. Mizuike, Rev. Anal. Chem., VI, 151 (1982).

3. M. Hiraide and A. Mizuike, Bunseki, 1992, 284 (1992).

4. M. Hiraide, T. Ito, M. Baba, H. Kawaguchi and A. Mizuike, Anal. Chem., 52, 804 (1980).

5. M. Hiraide, Z. S. Chen and H. Kawaguchi, Anal. Sci., 7, 65 (1991).

6. N. J. Sonawane, M. Hiraide and A. Mizuike, Anal. Chim. Acta, 149, 359 (1983).

7. S. Nakashima and Y. Yagi, Fresenius'Z. Anal. Chem., 314, 155 (1983).

8. M. Hiraide, J. Mizutani and A. Mizuike, Nippon Kagaku Kaishi, 1981, 161.

9. M. Hiraide, H. Hommi and H. Kawaguchi, Anal. Sci., 7, 169 (1991).

(Received December 2, 1992)

(Accepted March 16, 1993) 